\title{
An Overview of School Banking Program: Its Problems, Prospects and Acceptability (A Case Study on Janata Bank Limited Shamoli Corporate Branch)
}

\author{
Ghulam Rabbany, Din-il-Islam, Fatema Tus Sadia \\ Department of Agribusiness and Marketing, Faculty of Agribusiness Management, Sher-e-Bangla Agricultural University, Sher-e-Bangla \\ Nagar, Dhaka, Bangladesh
}

Email address:

tonoy_mkt@yahoo.com (G. Rabbany), dinilislam1983@gmail.com (Din-il-Islam), fatematussadia92@gmail.com (F. T. Sadia)

\section{To cite this article:}

Ghulam Rabbany, Din-il-Islam, Fatema Tus Sadia. An Overview of School Banking Program: Its Problems, Prospects and Acceptability (A Case Study on Janata Bank Limited Shamoli Corporate Branch). International Journal of Economics, Finance and Management Sciences. Vol. 3, No. 6, 2015, pp. 685-694. doi: 10.11648/j.ijefm.20150306.15

\begin{abstract}
JANATA Bank Limited was born with a new concept of purposeful banking sub serving the growing and diversified financial needs of planned economic development of the country. Very recently, BANGLADESH BANK has launched a scheme for the students named 'School Banking Scheme' through all commercial and specialized banks in Bangladesh. This concept is new as a separate product but became a popular one within two years with a view to inspiring for savings and creating savings mentality to the school going students with an attractive interest rate, waiver of service charges like other deposit accounts. BB issued a circular on 2nd November, 2010 to all commercial Banks for all school going students to be introduced with developed technology and banking services to play role in financial activities by savings. Up to this period more than 38 banks launched this scheme. But the rules and regulation to operate this kind of account is still ambiguous to all guardians as well as officials that how to open and operate, what necessary documents are needed to open this account from the students though every banks kept about all scheme through website. According to updated statistic of Bangladesh Bank Up to June'2011 to December'2011 more than 67 thousand 220 numbers of school banking accounts was opened and operated under banking jurisdiction. Approximately taka 31 crore was deposited under 29 thousand number of school banking accounts and taka 22 core 39 lac has been increased within six month difference. According to Private statistic there are 65 thousand and 428 numbers of accounts are in the form of school banking deposit account and deposit amount came to about taka 42 core 37 lac. Due to lack in publicity school banking scheme did not overcome its objectives like other deposit schemes. By this scheme most of students can able to build up capital for their future and besides this banks not only use to recurring deposit but also play a social role in the country. This program would be the milestone for the school banking operation for the students and guardians and for the bankers who will introduce the scheme.
\end{abstract}

Keywords: Economic Development, Interest Rate, School Banking Scheme, Service, Saving

\section{Introduction}

Bangladesh Bank (BB) on November 2, 2010 asked all scheduled banks to introduce School banking in a bid to establish financial inclusion across the country and encourage the students to savings-habit. Out of the 47 scheduled banks operating in the country, 36 have already launched the product in a large or small scale, according to source in the central bank. About 30,000 accounts have already been opened under various categories of school banking services in different banks across the country. Generally, School Banking runs all the way through primary school and sometimes through secondary schooling as well. For the students the concept includes banking education through regular school banking days, their own passbook, a reward system for taking part and 'saving up' for their chosen reward. School Banking programs are also important fundraisers for schools who usually receive a commission from the bank for the number of accounts opened and another for each deposit made by students. Usually, the institution that runs the particular School Banking program will provide a certain number of staff to administer the program but parents and volunteers are often relied on to fill in the gaps which they do admirably. It'san 
Interest bearing deposit account. Initial Balance - Tk. 100 . No hidden charge. Smart personalized (VISA) Debit Card to the parents. Round - the - clock ATM access across the country. No queues for withdrawal of money. Free SMS Banking. Cost free Mobile Banking Registration is the main features of school banking.

\section{Statement of the Problem}

School banking in Bangladesh is a very important issue and plays an important role for our economy specially for the school children. The activities of school banking are different from the activities of other conventional function of banking. School Banking follows the different rules and regulation for conducting its several activities. So it is necessary to know the overall activities and performance of School banking.

\section{Rationale of the Study}

There are many types of banking system in Bangladesh. One is conventional which is interest based another is Islamic, which is interest free. School banking operates their transactions in accordance with the principles of conventional way with low interest only for the benefit for the students. Teaching children the all-important skills of money management and saving when they are young can empower them for success in the future. That's where School Banking plays such an essential role. School Banking teaches valuable financial literacy skills that will last well beyond school life. A limited number of researches have been conducted on this topic. So a study convening all these issues becomes and expected to be very significant both from the practical view points to the best of knowledge of the researcher.

\section{Objective of the Study}

1. To know the basic concept of school banking

2. To know the functions and activities under school banking program.

3. To explore the problems related to school banking program.

4. To analyze customers acceptance towards this new service.

5. To know the future prospects of school banking.

6. To make some recommendation based on findings.

\section{Literature Review}

A brief summary of the researcher relevant to School banking is enumerated below will support this assumption:

Bangladesh Bank (BB) on November 2, 2010 asked all scheduled banks to introduce School banking in a bid to establish financial inclusion across the country and encourage the students to savings-habit. Out of the 47 scheduled banks operating in the country, 36 have already launched the product in a large or small scale, according to source in the central bank. About 30,000 accounts have already been opened under various categories of school banking services in different banks across the country. It's an interest bearing deposit account. Initial Balance - Tk. 100. No hidden charge. Smart personalized (VISA) Debit Card is provided to the parents. Cost free Mobile Banking Registration is the main features of school banking.

\section{Methodology of the Study}

Type of research.

Methodology provides various strategies and techniques to solve research problems. The following methodology will be followed for my study:

In this study, investigative (Exploratory Research) research will be conducted to find out and understanding of the overall school banking service. It's problems, prospects and acceptability of JANATA Bank Ltd. Shyamoli corporate branch.

Investigative Research.

Investigative research is conducted into an issue or problem where there are few or no earlier studies to refer to. The focus is on gaining insights and familiarity for later investigation. Secondly, descriptive research describes phenomena as they exist. Here data is often quantitative and statistics applied. It is used to identify and obtain information on a particular problem or issue. Finally causal or predictive research seeks to explain what is happening in a particular situation. It aims to generalize from an analysis by predicting certain phenomena on the basis of hypothesized general relationships.

\section{Opinion Poll Preparation.}

I designed a structure and unstructured questionnaire. This structured questionnaire was the major tools of this research project.30 questions are selected which focus the 6 objectives. And also for my study purpose, I have taken 50 respondents as my sample in another way. And 10 bank officers as respondent for some different questions. Five points scale is also used here for evaluation. The maximum number under each criterion is $250(50 \times 5)$.

The state different criteria in terms of the satisfaction of the customers is expressed in the points:

Table 1. Opinion Poll Marking System and Range.

\begin{tabular}{llll}
\hline Very Good & Total score & $201-250$ & Out of 250 \\
Good & Total score & $151-200$ & Out of 250 \\
Satisfactory & Total score & $101-150$ & Out of 250 \\
Moderate & Total score & $51-100$ & Out of 250 \\
Poor & Total score & $00-50$ & Out of 250 \\
\hline
\end{tabular}

Target Group.

Individual Customers of JANATA Bank Ltd. Shyamoly corporate branch and its employees.

Sources of Information

Primary Data.

Primary data (also called field research data) involves the collection of data that does not already exist, which is research to collect original data. Primary Research is often 
undertaken after the researcher has gained some insight into the issue by collecting secondary data. This can be through numerous forms, including questionnaires, direct observation and telephone interviews amongst others. This information may be collected in things like questionnaires and interviews. I have collected primary data by variety of ways, first of all by interviewing employees of JANATA Bank Ltd. and directly communicating with the customers. I have also conducted a questionnaire survey of the customers minimizing interruptions in their banking activities.

Secondary data.

Secondary data is data collected by someone other than the user. Common sources of secondary data for social science include censuses, surveys, organizational records and data collected through qualitative methodologies or qualitative research. I have elaborated different types of secondary data in my research. Sources of my secondary information's are:

Focus groups transcripts, Field notes, Observation records, Other personal, Research-related documents, Different books and periodicals related to the banking sector, Internet, Newspapers etc.

Data Collection Instruments.

In-depth interview: During the exploratory research, I conducted in-depth interviews with employees and customers of JANATA Bank Ltd.

Questionnaire survey: I also designed a structure and unstructured questionnaire for the customers of JANATA Bank. Shyamoli corporate branch. This structured questionnaire was the major tools of this research project.

Method and Size.

Technique.

During the survey of this project where customers were given copies of the questionnaire and were asked to fill them. I gave continuous support to the customers for any problems that they faced while filling up questionnaire so that the validity of the questionnaire increases. As the simple random sampling is easily understood and results are assessable it is best suited for my study. I asked questions to the bank officer, depositors and non-depositors.

Sample size.

In this report I selected 60 people for different analysis. I select the sample in following way:

Table 2. Sample Size.

\begin{tabular}{ll}
\hline Types of respondents & Number of respondents \\
\hline Bank Officers & 10 \\
Depositors & 20 \\
Non-Depositors & 30 \\
Total & 60 \\
\hline
\end{tabular}

Investigation system.

The analysis of collected data is completed with the help of the statistical tools. Here the value of the Likert scale $(5,4$, 3,2 , and 1) is counted as the weight. The response of the survey including the level of importance and the customer's perception are tallied at first and then the weighted average of those responses is prepared.

\section{Analysis of the Study}

\subsection{Overview of School Banking JANATA Bank Limited, Shyamoli Corporate Branch}

Name of the account: JANATA bank School banking program.

Opening account: School students aged between 6-18 years would be eligible for opening an account under school banking.

Form: In case of opening school bank account the guideline of Bangladesh financial intelligence unit launched on $30^{\text {th }}$ june 2008 , circular. Letter on AMLD-1 (policy) /2008-2324 will be applicable. For this account the students $\&$ parents both needed to submit personal information form. The signature of legal guardian is needed in both forms.

Nature of the account: It's a savings account. Student's such savings account can be transferred in any other type of savings scheme if needed.

Minimum initial deposit: This account can be opened with a minimum deposit of 100tk.

Citizenship: The account holder Student \& parents both must be the citizen of Bangladesh.

Necessary papers.

- Birth certificate of student.

- Attested copy of identity card /last month's due receipts from the school.

- Passport size attested photograph of student (2 copy )

- Passport size photograph of legal guardian with proper identification (2 copy )

- Received papers must be preserved in bank mandatorily.

Source of finance: It must be ensured that the source of fund is legal. And the transactions must be rational.

ATM card: ATM card (only debit) can be issued against this account. Monthly highest 2000 TK can be drawn at a time by this ATM card. But this amount can be increased up to $5000 \mathrm{Tk}$ based on the guardian's request. There should be a system of SMS transaction, alert in the guardians mobile when the transaction occur the detail information will go through SMS format to guardian's mobile.

Charges: Any kind of service charge or fee can't be charged without govt. fee from this account. These rules will also be applied on issuing \& renewing ATM card.

Students fee collections: Students school's monthly fee \& other payment can be collected through this account. Students of all schools should be covered under this program. The branches are trying to ensure that all students can get this banking service.

School bank counter: For helping the students in banking activities the branches can set up special counter or desk.

Money deposit from scholarship \& stipends: Money of all kinds of scholarship \& stipends can be deposited in this account.

Insurance facilities: With the accounts under school banking program education insurance facility will be given. So that students who are in financial problem in bearing educational expenses can be helped. 
In absence of account holder.

- In case of sudden death of account holder transaction can't be continued.

- In case of sudden death of account holder amount in account will be received by survivor (parents).

- In case of sudden death of account holder, guardian should submit following papers:

- Application.

- Death certificate of account holder.

- Letter of transmittal from local chairman/ ward commissioners.

- In case of death of parent/local guardian nominee will be receive the money.

Others: When account holder crosses 18 years old the account will turn on general savings account based on students consent.

Special directions.

- No loan will be permitted against this account.

- Minimum 100tk must be deposited each time.

- Lowest balance of account should be maintained 500tk.

- Cheque book issued in savings account will be issued for this account.

- Rules of interest are as like as others savings account.

Purpose.

The main purpose of this project is to create savings mentality in the school going students from a very young stage. To bring all students under banking service is another purpose.

Impact.

It has a great impact on our society. Students can know about banking activites from very begining of their life. They learn to be rational. Through school banking project a large number of new account are introduced. A large number of savings created which will strengthen the economic condition of our country. It can also help us to go one setp ahead on the way of being digital Bangladesh.

Acceptability.

As the program is new, many people are unaware of this project and can not understand its effectiveness properly. Number of interested gardian is few but educated and concious parents are eager to open school banking account for their children. Day by day the acceptance is increasing in the country. As there were no advertisements for this project people don't have good idea. But acceptability is increasing after taking different promotional activities. School banking is gradually getting popularity among the people due mainly to its some particular features including safe deposit and insurance coverage for their children and intimating the students with banking habit from early age.

Benefit.

- Some parents came to open bank account for their children but as in the past their was no system of opening account before 18 years old they became disappointed. Now this school banking project may help them.

- Bank will not claim any service charge against this account.
- They will also not claim the annual excise duty.

- There is a chance of getting scholership from world bank fund.

- Insurance facility is also given against this account.

- Banks are getting future clients.

- Country is getting more savings.

Problems.

- Maximum parents are unwilling to open a bank account for their kids. They think it's unnecessary. Convincing this type of parents is so tough.

- Poor parents think how they will diposite. They don't have enough money to save.

- Uneducated parents also don't pay any heed to it.

- As it is a joined account students can't draw money when they want, it depends on parent's choice.

\subsection{To Know the Basic Concept of School Banking (Awareness and Knowledge.)}

For customer.

Aspects relating to know about awareness and knowledge of customers about school banking are asked in 5 different questions. They are as follows.

\subsubsection{Have You Heard About School Banking}

a) Yes b) No.

Comment: For this question I asked 80 people both in the bank and outside the bank. Majority of the respondents express their positive feelings. $62.5 \% \quad(50$ persons $)$ respondent know about it, but $37.5 \%$ don't know.

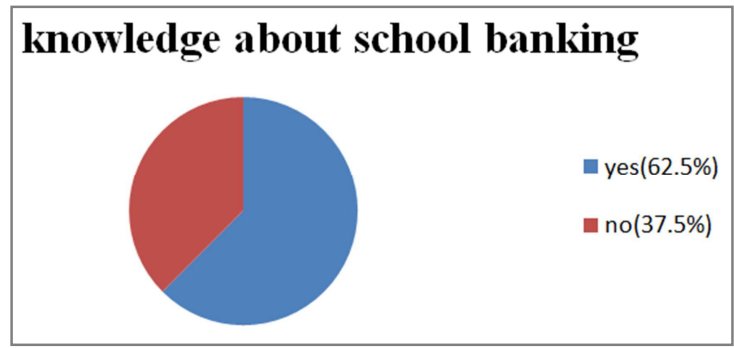

Figure 1. Knowledge about school banking.

\subsubsection{From Where You Have Heard About School Banking}

a) Bank b) Neighbor c) Friend d) Leaflet e) Other sources

Comment: Here I asked those 50 people who said that they know about it. Among them 40\% heard from banks, 10\% from neighbors, $24 \%$ from friends, $16 \%$ from leaflets and $10 \%$ heard from other sources.

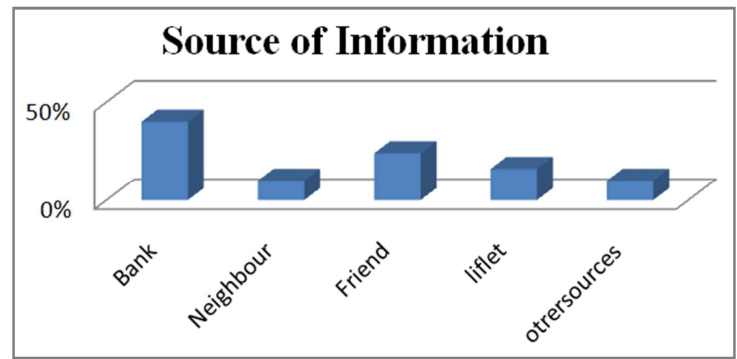

Figure 2. Source of information. 


\subsubsection{How Much You Know About It}

a) Very wellb) Moderatelyc) Not so welld) A little.

Comment: $40 \%$ respondents know school banking project very well. $30 \%$ know it moderately. $18 \%$ say that they know it not so well. And $12 \%$ have a very little knowledge.

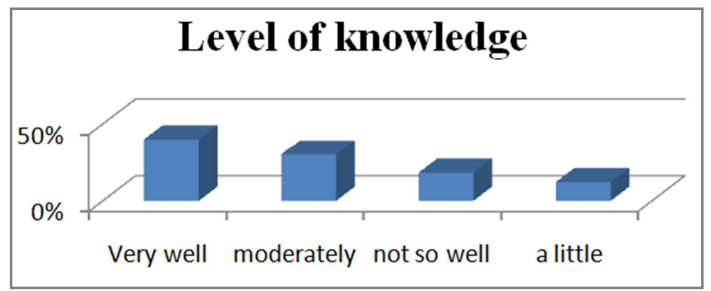

Figure 3. Level of knowledge about school banking.

\subsubsection{Your Interest on School Banking}

a) Agree b) Moderately agree c) Neither agrees nor disagrees d) Moderately disagree e) Strongly disagree.

Comment: $36 \%$ respondents strongly agreed with this atatement. 24\% moderately agreed. $8 \%$ doesn't give any opinion (neither agree nor disagree). 20\% moderately disagreed and $12 \%$ respondents strongly disagreed with this statement. The average point is 176 which indicate that customers are in a goose position in case of interest for school banking.

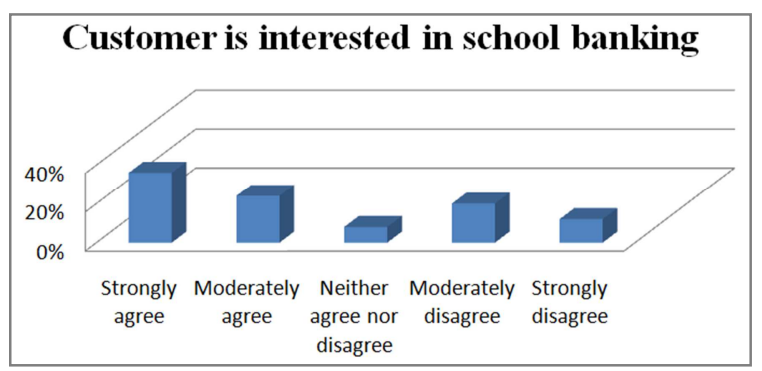

Figure 4. Customer's interest in school banking.

\subsubsection{Major Basic Concepts Level of School Banking in a Short View}

I have taken 50 respondents as my sample in another way. And 10 bank officers as respondent for some different questions. Five points scale is also used here for evaluation. The maximum number under each criterion is $250(50 \times 5)$.

The state different criteria in terms of the satisfaction of the customers is expressed in the points-

Table 3. Satisfaction of the customer for different criteria expressed in the point.

\begin{tabular}{llll}
\hline Very Good & Total score & $201-250$ & Out of 250 \\
Good & Total score & $151-200$ & Out of 250 \\
Satisfactory & Total score & $101-150$ & Out of 250 \\
Moderate & Total score & $51-100$ & Out of 250 \\
Poor & Total score & $00-50$ & Out of 250 \\
\hline
\end{tabular}

Major basic concepts level of school banking in a short view.

I have found the following results about their basic concept level of school banking from my selected questionnaire.
Table 4. Major basic concepts level of school banking in a short view.

\begin{tabular}{lllllll}
\hline $\begin{array}{l}\text { Very } \\
\text { Good }\end{array}$ & Good & Satisfactory & Moderate & Poor & Score & Position \\
\hline 18 & 12 & 04 & 10 & 06 & 178 & Good \\
\hline
\end{tabular}

\subsubsection{Why You Are Interested /not Interested}

a) it's new b) Its exciting c) It's not so good d)It's just waste e) Its nothing.

Comment: different person feel interest for different reason. in this study I found $24 \%$ respondent who think that school banking project is a new scheme and for that reason they are interested on it. $30 \%$ say it's exciting. $20 \%$ people think it's not so good. $18 \%$ considered it as a waste and $8 \%$ respondent regarded it as nothing.

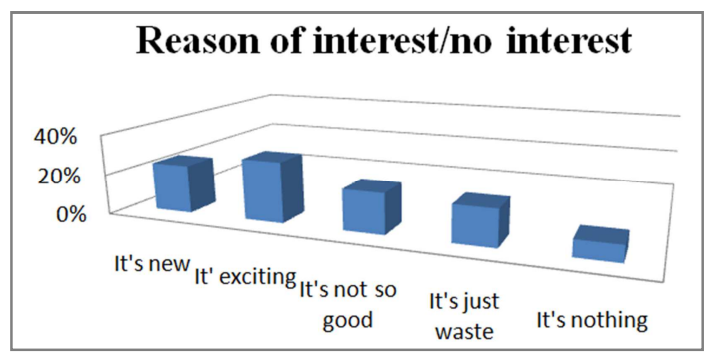

Figure 5. Reason of customer's interest for school banking.

\subsection{To Know the Problems (Customers; Guardians)}

Aspects relating to problems of school banking program were asked in three different questions to the customers. The results are as follows:

\subsubsection{What Type of Problems You Faced When Opening the Account}

a) Mortgageb) Introducerc) Fund shortage d) Other problems e) No problems at all.

Comment: $40 \%$ respondent faced problem of fund shortage, $30 \%$ faced some other problems and $30 \%$ respondent faced no problems at all.

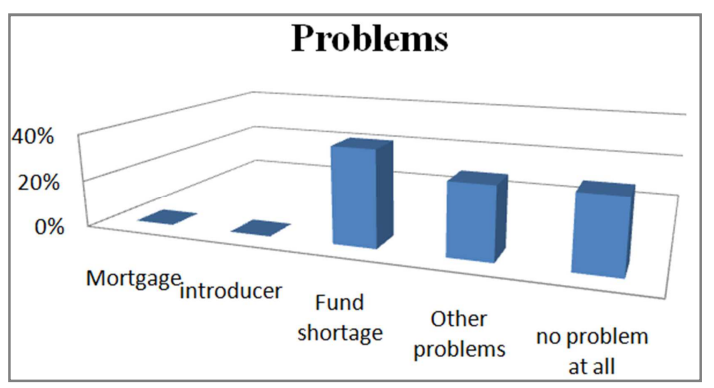

Figure 6. Types of problems faced by customers.

\subsubsection{What Amount You Needed to Deposited First Time}

a) 100 b) 500 c) $1000 d)>1000$

Comment: The minimum amount needed to be deposited first time is BDT 100. but some parents also deposit more than it.50\% respondent deposit $100 \mathrm{tk}, 40 \%$ deposit $500 \mathrm{tk}$, $6 \%$ deposit 1000 tk and only 4\% respondent deposit more than 1000 tk first time. 


\subsubsection{Do the Bank Employees Force You to Open the Account}

a)Yes b) No.

Comment: sometimes it happens that the bank employees try to force some guardians to open account in their branch to fulfill their target. Here $94 \%$ respondent said that they were not forced by employees but $6 \%$ respondent said they were forced.

\subsection{Finding Customers Outlook / Acceptance Towards School Banking (for Both Students and Their Guardians)}

Six attributes were grouped in this dimension and the respondents were asked to express their opinions about the acceptability of school banking to them. Results are shown below:

\subsubsection{Is the Scheme}

a) Worse b) Bad c) Good d) Better e) Best.

Comment: $4 \%$ respondent marked it as worse. $10 \%$ considered as bad. $40 \%$ think it as a good scheme. $40 \%$ said its better. And 16\% answered that the scheme is best for students.

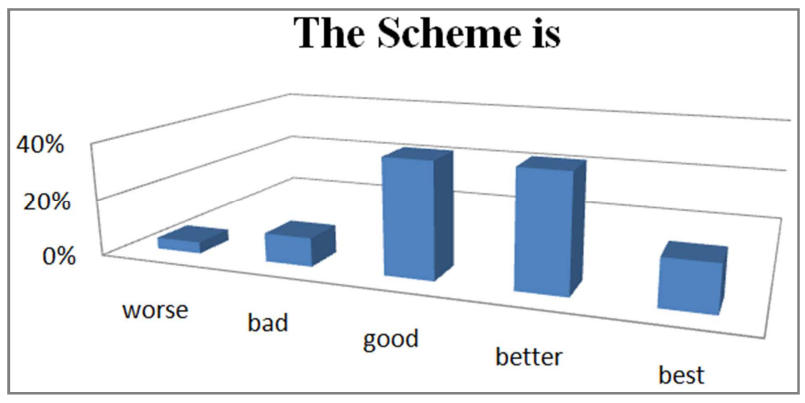

Figure 7. About the scheme.

\subsubsection{Have You Opened an Account}

a) Yes b) No c) I'll open after some days

Comment: $20 \%$ respondent has already opened the account. 36\% haven't. And 24\% respondents hope that they'll open a school banking account near future.

\subsubsection{How You Feel After Opening/not Opening a School Banking Account}

a)Secure b)Insecure c)Wealthy d) Older than before

Comment: $50 \%$ account holder feel them secure after opening the account. $30 \%$ feel wealthy. $20 \%$ students feel them older than before. But no one feel insecure.

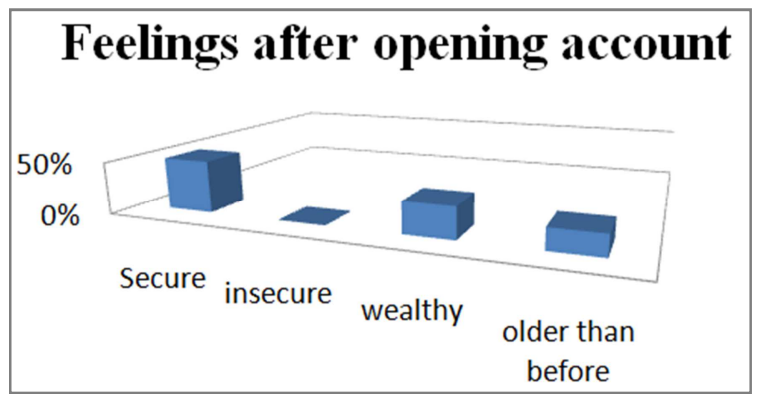

Figure 8. Feelings of customers after opening school banking account.

\subsubsection{Its Meaning to the Children's}

a) Savings b) Expense c) Money management d) Marketing e) Banking.

Comment: $44 \%$ respondent think that children will learn to save after having an account. 5\% think they will learn to expense properly. $40 \%$ respondent hope that children will learn money management. And 6\% respondent said they will have banking experience.

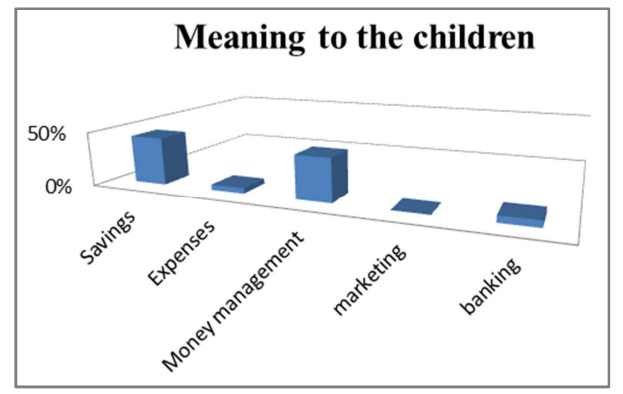

Figure 9. Meaning to the children from school banking.

\subsubsection{Do You Say Anything to Another Parson About It}

a) Yes b) No

Comment: when the customers feel better about their decision of opening a school banking account they also spread positive word of mouth to others. Here $40 \%$ respondent discussed it with other people, but $60 \%$ didn't.

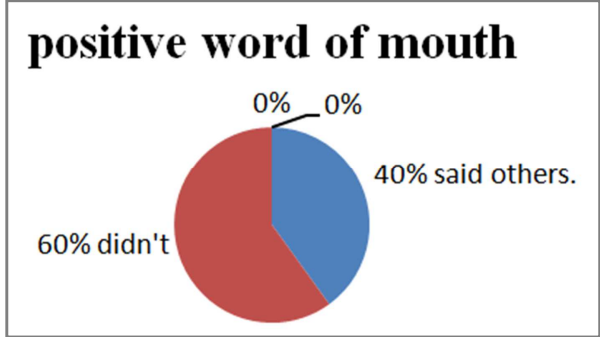

Figure 10. Positive word of mouth

\subsubsection{How They React After Hearing It}

a) Show positive expression b) Expressed negatively c) Just passed away d) Also wanted to open an account.

Comment: when the customers share their new experience about school banking with other people they react in different way. $30 \%$ show positive expression. $24 \%$ expressed negatively. $20 \%$ just passed away. And $26 \%$ wanted to open an account hearing from them.

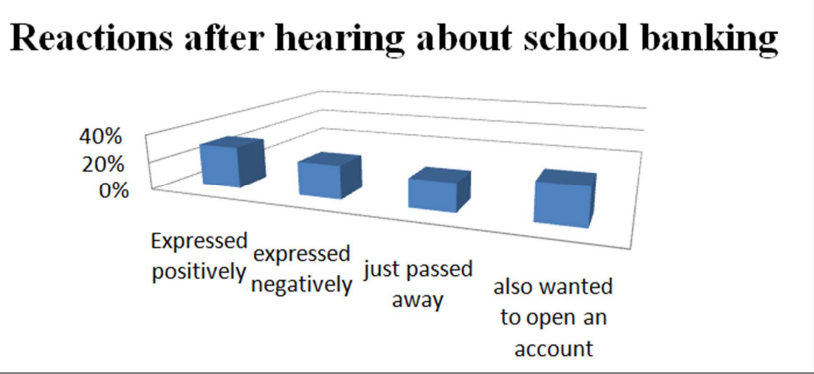

Figure 11. Reactions of other people after hearing about school banking 


\subsection{Finding Future Prospects (Students)}

Six questions relating to the future prospect of school banking were asked to the respondents. The results are as below:

\subsubsection{From Where You Deposit}

a) A part of my tiffin money b) Gift from others c) Daddy gives the money d) Mummy gives the money.

Comment: $40 \%$ student saves from their tiffin money. $10 \%$ deposited from gift from others. $28 \%$ said their father give the money and $22 \%$ said their mother give the money.

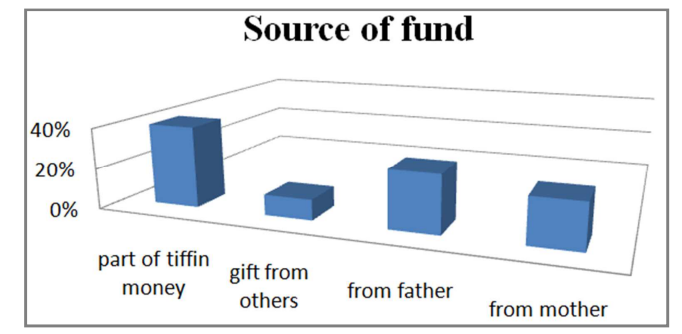

Figure 12. Source of fund.

\subsubsection{How It Help You}

a) I can use this account for all types of school payment b) I can save money c) I can reduce my unnecessary expenses.

Comment: $50 \%$ student think the account helpful for their school payment. $30 \%$ consider it helpful for saving money. And $20 \%$ think this account reduces their unnecessary expenses.

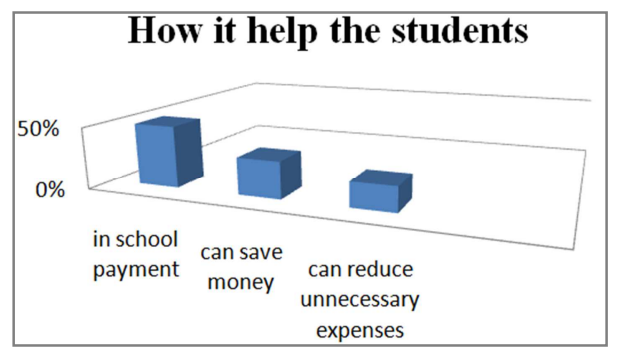

Figure 13. How it helps the students.

\subsubsection{Do You Get Any Other Benefit}

a) Interest b) Scholarship c) Knowledge d) No special benefit.

Comment: $60 \%$ students consider the interest as their benefit. $15 \%$ think they are benefited through gaining knowledge. $25 \%$ said they are not getting any special benefit till then.

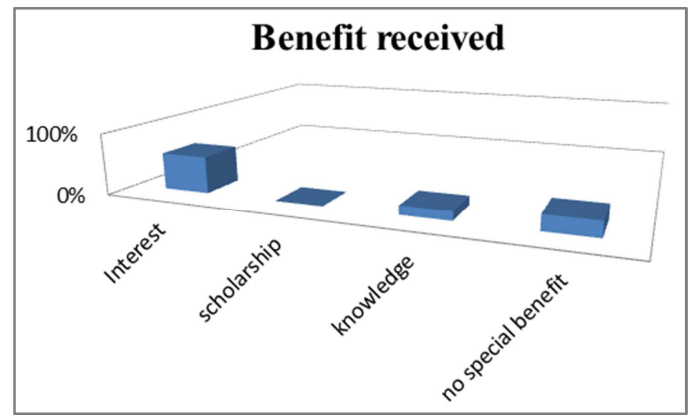

Figure 14. Benefits received by students

\subsubsection{Do You Want to Continue This Account}

a) Yesb) No.

Comment: $90 \%$ respondent wanted to continue the account. And 10\% didn't.

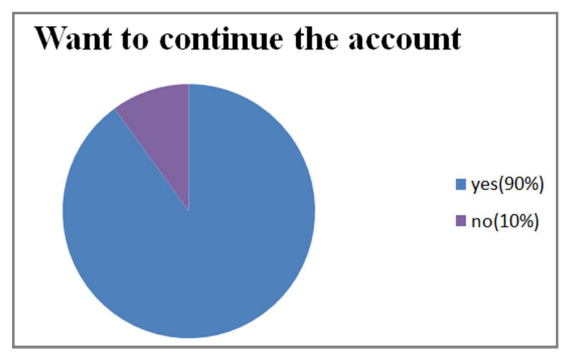

Figure 15. Respondents willing to continue the account.

\subsubsection{What Will You Do in Future (After 18 Years Old) with This Account}

a) It'll automatically turn in savings account b) I'll close it. Comment: only $10 \%$ respondent wanted to close it.

\subsubsection{Do You Want to Give Any Suggestion About the Scheme}

a) Less money requirement for opening account b) Increase interest rate c) Increase the number of scholarship d) No suggestion.

Comment: $20 \%$ respondent suggests reducing money requirement to open. $30 \%$ suggest to increase interest rate. $26 \%$ suggest increasing the number of scholarship and $24 \%$ respondent don't give any suggestion.

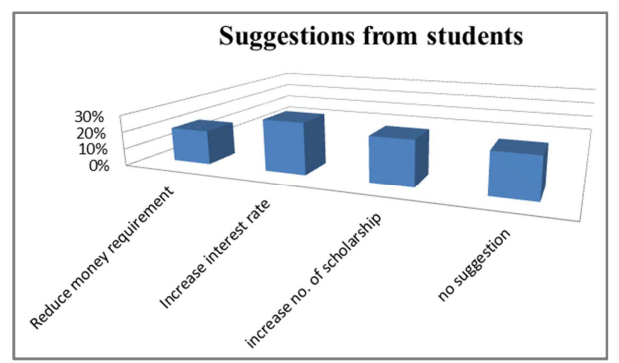

Figure 16. Students suggestions for school banking.

\subsection{To Know the Function and Activities (10 Bank Officers)}

6 attributes related to the functions and activities of school banking program were grouped in this part. In JANATA Bank Limited, Shyamoly corporate branch I have found only ten employees who expressed their views. The maximum numbers under each criterions is $50(10 \times 5)$. The state of different criterion in terms of the satisfaction of the customers is expressed in the points:

Table 5. Different criterion in terms of the satisfaction of the customersexpressed in the points. (10 bank officers view).

\begin{tabular}{llll}
\hline Very Good & Total score & $41-50$ & Out of 50 \\
Good & Total score & $31-40$ & Out of 50 \\
Satisfactory & Total score & $21-30$ & Out of 50 \\
Moderate & Total score & $11-20$ & Out of 50 \\
Poor & Total score & $01-10$ & Out of 50 \\
\hline
\end{tabular}




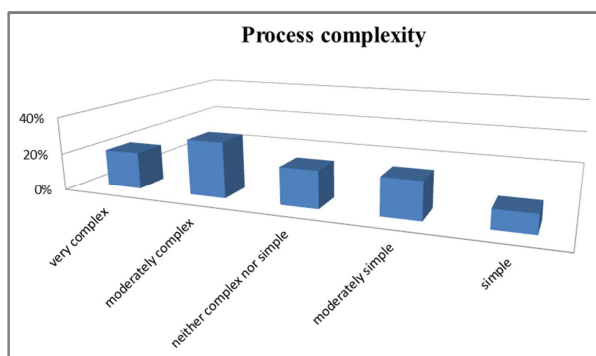

Figure 17. Complexity of the process.

\subsubsection{Is the Process Complex}

a) Very complex b) Moderately complex c) Neither complex nor simple d) Moderately simple e) Simple.

Comment: $20 \%$ officer think it as very complex process. They think customers can't understand it for its complexity. $30 \%$ consider it as moderately complex. $20 \%$ say it's neither complex nor simple. $20 \%$ judge it as moderately simple. and $10 \%$ think it's simple. Average score is 33 out of 50 (good). which indicates that the process is complex to many people.

\subsubsection{Overall Activities and Functions of This Bank About \\ This Service}

From the employee I have found the following major findings about functions of this bank about school banking service.

Table 6. Overall activities and functions of this bank about School banking service.

\begin{tabular}{lllllll}
\hline $\begin{array}{l}\text { Very } \\
\text { Good }\end{array}$ & Good & Satisfactory & Moderate & Poor & Score & Position \\
\hline 02 & 03 & 02 & 02 & 01 & 33 & Good \\
\hline
\end{tabular}

\subsubsection{How Many Parties Needed Here}

a) Only the student $b$ ) The student and their parent c) Need of introducer d) There are so many parties.

Comment: $80 \%$ officer answered that here needed two parties students and their parents. $20 \%$ said there is needed many parties.

\subsubsection{What Is the Interest Rate of This Scheme}

a) $5 \%$ b) $6 \%$ c) $8 \%$ d) $10 \%$.

Comment: all the respondents answered 6\%.

\subsubsection{Do You Face Any Problem Handling Customers Under This Scheme}

a) Many problems b) Some problems c) No problems.

Comment: $50 \%$ respondent faced many problems. $30 \%$ faced some problems and $20 \%$ faced no problems.

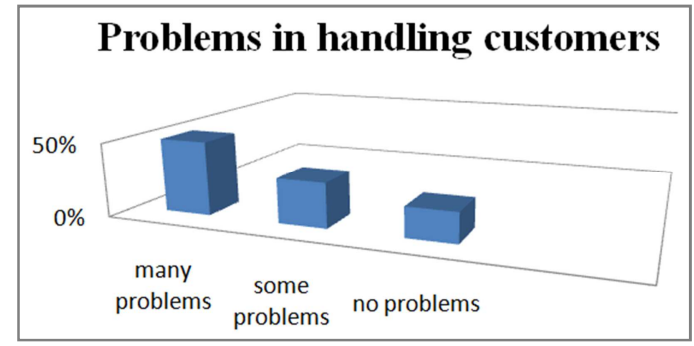

Figure 18. Problems in handling customers of school banking scheme.

\subsubsection{Acceptance of Customer}

a) Strongly agree b) Moderately agree c) Neither agrees nor disagrees d) Moderately disagree e) Strongly disagree.

Comment: $10 \%$ employee strongly agreed. $20 \%$ officer moderately agreed, $10 \%$ neither agree nor disagree, $20 \%$ moderately disagreed and $40 \%$ strongly disagreed with this statement. The average score is 24 out of 50 which indicates satisfactory result.

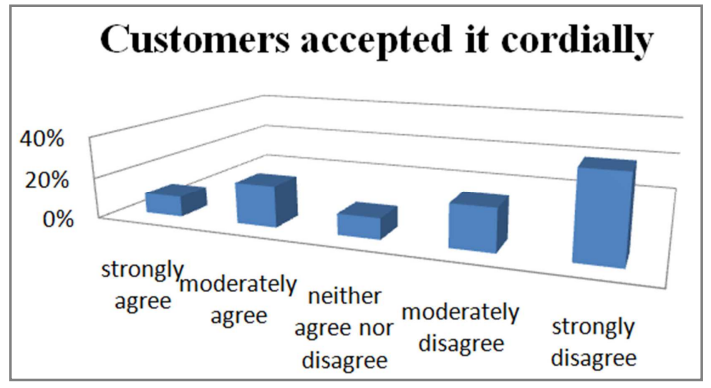

Figure 19. Customers acceptance.

\subsubsection{Overall Customer Acceptance Measured by Service Provider in a Short View}

By the above analysis and using those findings the following table will give us a short view of overall customer acceptance that is measured by service provider.

Overall customer acceptance measured by service provider in a short view.

Table 7. Overall customer acceptance by service provider level.

\begin{tabular}{lllllll}
\hline $\begin{array}{l}\text { Very } \\
\text { Good }\end{array}$ & Good & Satisfactory & Moderate & Poor & Score & Position \\
\hline 01 & 02 & 01 & 02 & 4 & 24 & Satisfactory \\
\hline
\end{tabular}

\subsubsection{Is There Any Need of Mortgage}

a) Yes b) No.

\subsection{Finding Problems (Bank Officers)}

Four questions relating to the problems faced by the bank employees were asked. The results are shown below:

\subsubsection{How You Convinced the Students}

a) Try to encourage them b) Give them knowledge about it c) Convinced their parents d) Forced them.

Comment: all the employees who are responsible for school banking program of Janata bank shyamoly corporate branch trying their best to convince the student for opening an account under this scheme. $30 \%$ employee try to encourage them. $40 \%$ give them knowledge about its scholarship facility, $20 \%$ convinced student's parents and $10 \%$ try to partially force them in different way.

\subsubsection{It's a Very Tiresome Job to Manage/Collect Customer for School Banking}

a) Strongly agree b) Moderately agree c) Neither agrees nor disagrees d) Moderately disagree e) Strongly disagree.

Commentate bank officers are working hard to fulfill their target of school banking program. 50\% employee strongly agreed with this statement. $30 \%$ moderately agree. $10 \%$ 
neither agree nor disagree and $10 \%$ moderately disagree. The average score is 42 out of 50 (very good). which indicates that maximum employee consider it as a very hard job.

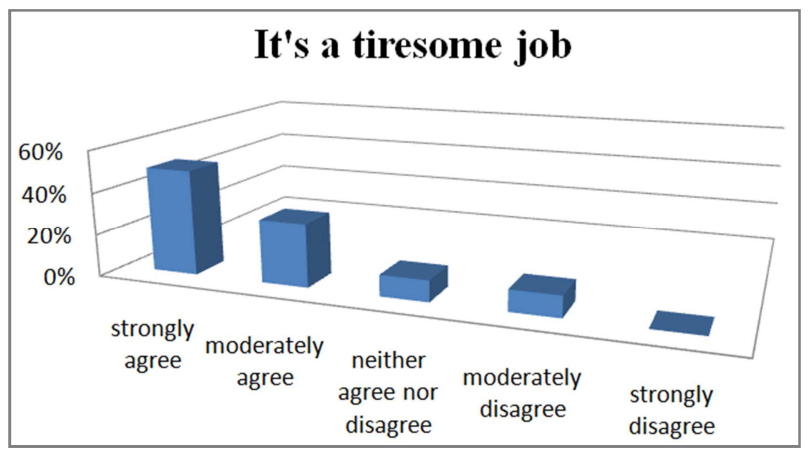

Figure 20. It's a tiresome job.

\subsubsection{Where You Get Them}

a) Nearby schools b) In my bank c) In my locality d) My child's friends e) Others.

Comment: Bank employees are collecting customers from different places. They get $50 \%$ customers from nearby schools. $20 \%$ from the bank (their working place), $12 \%$ from their locality, $10 \%$ among their children's friends, and $8 \%$ from other sources.

\subsubsection{What's Your Benefit}

a) We get future customer b) Get benefit from Govt. c) Get promotion d) No benefit.

Comment: through school banking program $60 \%$ employee think they are getting future customer. $20 \%$ think they'll get benefit from Govt. 10\% hope to get promotion. And 10\% think they are not getting any benefit.

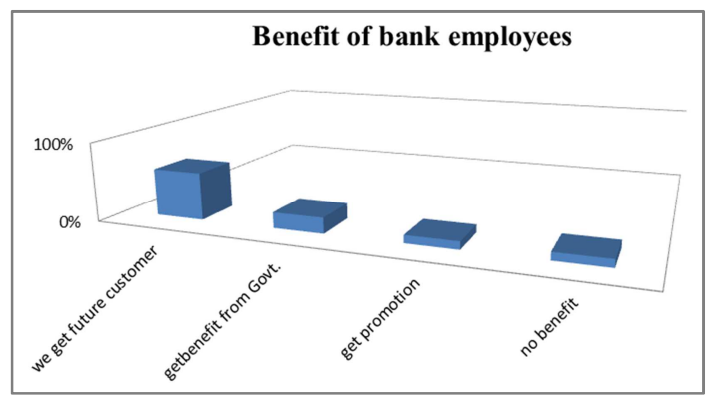

Figure 21. Benefit of bank employees.

\section{Major Findings}

1. To develop my practical knowledge I had to attach with my respective organization (JANATA Bank Ltd Shyamoly corporate Branch.) three months and I have found that their banking works, environment, culture, discipline, norms, employee behavior towards clients was really satisfactory

2. Though the employees are trying a lot, the process of opening the account still seems to be a little bit hard to some guardians. In those cases bank employees are helping them.
3. Some employees consider it as a very difficult job to acquire a large number of students each year.

4. The bank has already achieved its target to reach 180 school banking account under the branch. It's still trying to bring many more students under their banking service.

5. The bank has able to advertise the new program and inform the students and their guardians about school banking properly. Most of the students of nearby schools have clear idea about it.

6. They also able to create interest in students mind. Maximum customers regard it as so exciting. The students and guardians are mostly interested about the insurance and scholarship facility of school banking program.

\section{Conclusion}

As an internee of JANATA Bank Ltd., I have truly enjoyed my internship from the learning and experience viewpoint. I am confident that this three months internship program at JANATA Bank will definitely help me to realize my future carrier in the job market. As there are lots of local and foreign banks in Bangladesh the JANATA Bank Ltd. is promising commercial Bank among them. In this competitive market JANATA Bank has to compete not only the other commercial banks but also with the multinational Bank. JANATA Bank Ltd. is more capable of contributing towards economic development as compared with other bank. The bank launched school banking program about one year back but didn't get satisfactory responses. But now a day it is becoming a very promising sector. The offer of bearing study cost up to 18 years of the account holder students, if they unfortunately lost their parents, is mainly promoting the customers to accept the product. The more profit the bank earn, the more benefit the account holders will get; awarding the student for brilliant results. JANATA Bank does not see school banking as a profit making business. But they hope that many of these students would become their customers in future.

\section{Recommendations}

1. Promotional activities like ads, regular articles, and social programs regarding School banking should be arranged.

2. Speed of services need to improve.

3. Some special reward for students against these accounts can be introduced.

4. Special remuneration for employees who are responsible for school banking program may encourage their hard workings and increase their satisfaction.

\section{References}

[1] Annual reports of JANATA Bank Ltd. 2014, 2013, 2012.

[2] Khan. M. Y. And Jain, P. K: Financial Management, Tata McGraw-Hill. 
[3] Kothari, C. K. Research Methodology.

[4] Pandy, I. M: Financial Management.

[5] Rose and wester field: Financial Management

[6] Hannan, A. S. and Shaheed, A. 1998 Financial Position and Performance analysis of Bangladesh Shilpa Bank, Islamic University Studies, Volume-1, June 1998.
[7] Shekar, K. C.: Bank Management.

[8] Shekar, K. C.: Banking Theory and Practice.

[9] Malhotra, N. K.: Marketing Research.

[10] Straub, J.; Attner, R. F: Introduction to Business. 